\title{
Stories To Inspire Very Young Engineers: Can Robots Burp?
}

Allison Lague; Stephanie McCartan; AnnMarie Thomas, University of St. Thomas

\begin{abstract}
The importance of reading to preschool and kindergarten aged children has been well documented. This paper presents in-progress work developing a methodology for assessing the engineering and STEM content in books intended for this age group. Of particular interest is whether the STEM content is portrayed accurately. We present a sample investigation and rubric, focusing on robots.
\end{abstract}

\section{Introduction}

As part of a larger effort in the University of St. Thomas Center for Engineering Education, a group of engineering students and faculty are developing activities for parents/caretakers and preschool aged children to do together with minimal intervention from instructors. The goal of the project is to have a set of materials, and written guides, that adults with no STEM background can use with three to five year old children, exploring engineering content.

Teaching through stories is a natural way for children to learn because the brain constantly works with narratives, which means that recalling stories is easier than recalling facts learned from lists $^{1}$. Additionally, many parents report storybooks to be the most important tool for the development of their children ${ }^{2}$. With this in mind, it is logical that parents or caregivers use storybooks to teach and allow children to form opinions on science fields. In addition to stimulating new ideas and concepts, storybooks are important in developing empathy. The attitudes that young children have towards science are often lasting attitudes ${ }^{3}$.

The idea of using stories to engage children in engineering isn't new. Engineering is Elementary (EiE) is a story-based curriculum that incorporates hands-on activities to teach elementary aged children about engineering. The EiE curriculum has been used in all 50 states, as well as more than 60 schools in Minnesota ${ }^{4,5}$. Although the use of the EiE curriculum is widespread, there still are not many programs dedicated to the P-K level. In fact, the National Academy's review of existing engineering programs lists only one P-K program and eight elementary programs ${ }^{6}$.

Children are not often explicitly told what an engineer is or does. Because of this, many children have very narrow and naïve views of what an engineer is; children often associate the term "engineer" with something along the lines of an auto mechanic or construction worker ${ }^{7}$ Other common misconceptions include the thought that engineering is: a desk job, something that is only related to science and math, and that engineering is a field that doesn't directly help others $^{8}$. The EiE definition of technology ${ }^{9}$ is "anything made by humans to fill a need or desire." A broader, standards-based definition of technology and an expanded view of what an engineer does combined with early experiences with engineering encourage students to continue down STEM career pathways ${ }^{10}$.

Based on these findings, it was decided that activities would be developed around picture books that parents/caretakers and children could read together before undertaking the related activities. 


\section{Does the Content Matter?}

While themes of fantasy and magic are popular in picture books, it was our desire that books chosen for this project present engineering topics in an accurate manner. It became clear, however, that determining to what level the material needed to be accurate could be a bit challenging in a genre that often involves talking animals. Our approach, then, was to look at relevant academic standards and use these to develop a rubric for assessing content in the picture books being considered.

For our first activity unit we wanted to choose a book, or books, that portray robots in a manner that is, reasonably, accurate with regards to technological capabilities and engineering design processes. Of particular interest to us was that the book could be used to reinforce concepts that the children would be exposed to according to the Minnesota Academic Standards in Science.

\section{Rubric}

We selected five criteria for our initial robotics picture book rubric, based on a combination of the Minnesota Academic Standards in Science ${ }^{11}$ and the Next Generation Science Standards ${ }^{12}$.

\section{(1) Life source/ creation of robot}

Standard is 0.1.1.2.1. for Kindergarteners (in strand: substrand The Nature of Science and Engineering: The Practice of Engineering) in the Minnesota Academic Standards in Science is:

"Understand that some objects occur in nature; others have been designed and processed by people."

The benchmark for this standard is being able to:

"sort objects into two groups: those that are found in nature and those that are human made."

Some robotics picture books that we encountered explicitly show that robots are man made, while others imply that they have robot parents.

\section{(2) Freedom to act and move}

The second criterion was chosen based on the accuracy of the content presented. It is not directly tied to any standards.

\section{(3) Defining Engineering Problems}

Standard ETS1.A: Defining Engineering Problems from the Next Generation Science Standards for Kindergarteners states: 
"A situation that people want to change or create can be approached as a problem to be solved through engineering. Such problems may have many acceptable solutions."

The benchmark for this standard is being able to:

"Ask questions, make observations, and gather information about a situation people want to change to define a simple problem that can be solved through the development of a new or improved object or tool."

\section{(4) Developing Possible Solutions}

Standard ETS1.B: Developing Possible Solutions in the Next Generation Science Standards for Kindergarteners states:

"Designs can be conveyed through sketches, drawings, or physical models. These representations are useful in communicating ideas for a problem's solutions to other people."

The benchmark for this standard is being able to:

"Develop a simple sketch, drawing, or physical model to illustrate how the shape of an object helps it function as needed to solve a given problem."

\section{(5) Optimizing the Design Solution}

Standard ETS1.C: Optimizing the Design Solution from the Next Generation Science Standards for Kindergarteners states:

"Because there is always more than one possible solution to a problem, it is useful to compare and test designs."

The benchmark for this standard is being able to:

"Analyze data from tests of two objects designed to solve the same problem to compare the strengths and weaknesses of how each performs."

\begin{tabular}{|c|c|c|c|}
\hline & + & $\mathbf{0}$ & - \\
\hline $\begin{array}{c}\text { (1) Life source/ } \\
\text { creation of } \\
\text { robot }\end{array}$ & $\begin{array}{c}\text { Robot is } \\
\text { constructed }\end{array}$ & Not mentioned & $\begin{array}{c}\text { Robot comes from robot } \\
\text { parents or nature }\end{array}$ \\
\hline
\end{tabular}




\begin{tabular}{|c|c|c|c|}
\hline $\begin{array}{c}\text { (2) Freedom to } \\
\text { act and move }\end{array}$ & $\begin{array}{c}\text { Robot moves how } \\
\text { it is programmed }\end{array}$ & $\begin{array}{c}\text { Realistic motion, } \\
\text { but programming } \\
\text { is not mentioned }\end{array}$ & $\begin{array}{c}\text { Robot moves however it } \\
\text { wants - flying, } \\
\text { skateboarding, etc. }\end{array}$ \\
\hline $\begin{array}{c}\text { Engineering } \\
\text { Problems }\end{array}$ & $\begin{array}{c}\text { Story presents a } \\
\text { problem that can } \\
\text { be solved with } \\
\text { engineering. }\end{array}$ & Not mentioned & \\
\hline $\begin{array}{c}\text { (4) Developing } \\
\text { Possible } \\
\text { Solutions }\end{array}$ & $\begin{array}{c}\text { Multiple solutions } \\
\text { are presented as } \\
\text { possibilities }\end{array}$ & Not mentioned & \\
\hline $\begin{array}{c}\text { (5) Optimizing } \\
\text { the Design } \\
\text { Solution }\end{array}$ & $\begin{array}{c}\text { Different } \\
\text { solutions are } \\
\text { best one is chosen }\end{array}$ & Not mentioned & \\
\hline
\end{tabular}

\section{Book Selection}

As the intended locations for these activities consist of libraries, homes, and museums, we restricted our initial robot picture book search to books found in the juvenile picture book (JUV) section of a local branch of the St. Paul Public Library. By choosing to base our activities on books that are available at libraries, we hope to increase the number of families that can use the activities.

Thus, we looked at the following:

- $\mathrm{Boy}+\mathrm{Bot}^{13}$

- Baby Brains and RoboMom ${ }^{14}$

- The Robot and the Bluebird ${ }^{15}$

- When Edgar Met Cecil ${ }^{16}$

- Marveltown ${ }^{17}$

- Robot Zot! ${ }^{18}$

- Robot Burp Head Smartypants! $!^{19}$

- Robot Zombie Frankenstein! ${ }^{20}$

- Superhero 21

- Robomop 22

- CookieBot! ${ }^{23}$

- Doug Unplugged ${ }^{24}$

- Sometimes I Forget You're A Robot ${ }^{25}$ 


\section{Test Rubric With Books}

To test this rubric, we used the thirteen books listed above. The titles are listed again below the sample rubric. Each title will have two corresponding numbers. An example would be as follows:

\section{Title (\#)}

In this case, the 00 would be the number of the book that would appear on the rubric in the boxes that best fit the story. Each box has a corresponding number valued at $-1,0$, or 1 . This is represented in the column heads as,+ 0 , or - . Then, the sum of these numbers is taken for each title. For example, if 00 occurred twice in the ' + ' column, three times in the ' 0 ' column, and once in the '-' column, its score would be: $2(1)+3(0)+1(-1)=1$. This number would then occur after the title in parentheses, so our example would now be:

00 . Title (1).

\begin{tabular}{|c|c|c|c|}
\hline & + & 0 & - \\
\hline $\begin{array}{l}\text { (1) Life source/ } \\
\text { creation of } \\
\text { robot }\end{array}$ & $\begin{array}{c}\text { Robot is } \\
\text { constructed } \\
1,2,5,9,10,11\end{array}$ & $\begin{array}{l}\text { Not mentioned } \\
\text { 3, 6, 7, 8, } 13\end{array}$ & $\begin{array}{l}\text { Robot comes from robot } \\
\text { parents or nature } \\
4,12\end{array}$ \\
\hline $\begin{array}{l}\text { (2) Freedom to } \\
\text { act and move }\end{array}$ & $\begin{array}{c}\text { Robot moves how } \\
\text { it is programmed } \\
\text { or told } \\
5,11,13\end{array}$ & $\begin{array}{l}\text { Realistic motion, } \\
\text { but programming } \\
\text { is not mentioned } \\
1,2,3,8,9,10\end{array}$ & $\begin{array}{l}\text { Robot moves however it } \\
\text { wants - flying, } \\
\text { skateboarding, etc. } \\
\text { 4, 6, 7, } 12\end{array}$ \\
\hline $\begin{array}{l}\text { (3) Defining } \\
\text { Engineering } \\
\text { Problems }\end{array}$ & $\begin{array}{c}\text { Story presents a } \\
\text { problem that can } \\
\text { be solved with } \\
\text { engineering. } \\
2,4,5,6,9,10 \text {, } \\
11,13\end{array}$ & $\begin{array}{l}\text { Not mentioned } \\
1,3,7,8,12\end{array}$ & \\
\hline $\begin{array}{l}\text { (4) Developing } \\
\text { Possible } \\
\text { Solutions }\end{array}$ & $\begin{array}{l}\text { Multiple solutions } \\
\text { are presented as } \\
\text { possibilities } \\
2,5,9,10\end{array}$ & $\begin{array}{c}\text { Not mentioned } \\
\begin{array}{c}\text { 1, 3, 4, 6, 7, 8, 11, } \\
12,13\end{array}\end{array}$ & \\
\hline
\end{tabular}




\begin{tabular}{|c|c|c|c|}
\hline & + & $\mathbf{0}$ & - \\
\hline $\begin{array}{c}\text { (5) Optimizing } \\
\text { the Design } \\
\text { Solution }\end{array}$ & $\begin{array}{c}\text { Different } \\
\text { solutions are } \\
\text { compared \& the } \\
\text { best one is chosen } \\
2\end{array}$ & $\begin{array}{c}1,3,4,5,6,7,8, \\
9,10,11,12,13\end{array}$ & \\
\hline
\end{tabular}

1. Boy + Bot (1)

2. Baby Brains and RoboMom (4)

3. The Robot and the Bluebird (0)

4. When Edgar Met Cecil (-1)

5. Marveltown (4)

6. Robot Zot! (0)

7. Robot Burp Head Smartypants! $(-1)$

8. Robot Zombie Frankenstein! (0)

9. Superhero (3)

10. Robomop (3)

11. CookieBot! (3)

12. Doug Unplugged (-2)

13. Sometimes I Forget You're A Robot (2)

From this rubric we were able to get a sense of which picture books are most aligned with the criteria that we were hoping to explore in our activities.

\section{Conclusions and Future Work}

This paper shows the initial development of a method for assessing the content of STEM themed picture books, particularly those related to robots. During the 2014-15 school year we will be refining our methods of assessing picture books and developing parent/caretaker and child activities to go along with the chosen books. These activities will be tested in libraries and museum settings.

\section{Bibliography}

1. Wilson, E. O. (2002). The Power of Story. American Educator, 26(1), 8-11.

2. Rideout, V.J., Vandewater, E.A., and Wartella, E.A., (2003). Zero to six: electronic media in the lives of infants, toddlers and preschoolers. Henry J. Kaiser Family Foundation, Menlo Park, CA. www.kff.org 
3. Pell, T., \& Jarvis, T. (2001). Developing attitude to science scales for use with children of ages from five to eleven years. International Journal of Science Education, 23(8), 847-862.

4. Engineering is Elementary. (n.d.). EiE Curriculum FAQs. Retrieved August 4, 2014, from http://www.eie.org/eie-curriculum/eie-curriculum-faqs

5. Engineering is Elementary - EiE in Minnesota. (n.d.). Science Museum of Minnesota. Retrieved August 4, 2014, from http://www.smm.org/eie/minnesota

6. Kaheti, L., Pearson, G., and Feder, M. (Eds). (2009). Engineering in K-12 Education: Understanding the status and improving the prospects. National Academy of Engineering and National Research Council. Washington, D.C., National Academies Press.

7. Knight, M. \& Cunningham, C. M. (2004). Draw an Engineer Test (DAET): Development of a tool to investigate students' ideas about engineers and engineering. In ASEE Annual Conference and Exposition. Salt Lake City, UT: American Society for Engineering Education.

8. National Academy of Engineering, (2008). Changing the Conversation: Messages for Improving Public Understanding of Engineering, National Academies Press, Washington, DC.

9. Science, Engineering, \& Technology. (n.d.). Engineering is Elementary. Retrieved August 4, 2014, from http://www.eie.org/overview/science-engineering-technology

10. Why Engineering for Children?. (n.d.). Engineering is Elementary. Retrieved August 4, 2014, from http://www.eie.org/overview/engineering-children

11. Minnesota Academic Standards: Science K-12. (2009).

12. Performance Expectations. (n.d.). Next Generation Science Standards. Retrieved August 4, 2014, from http://www.nextgenscience.org/search-performance-expectations

13. Dyckman, A., \& Yaccarino, D. (2012). Boy and Bot. : Random House Children's Books.

14. James, S. (2008). Baby Brains and RoboMom. Cambridge, Mass.: Candlewick Press.

15. Lucas, D. (2008). The Robot and the Bluebird. New York: Farrar, Straus and Giroux.

16. Luthardt, K. (2013). When Edgar met Cecil. Atlanta: Peachtree.

17. McCall, B. (2008). Marveltown. New York: Farrar, Straus and Giroux.

18. Scieszka, J., \& Shannon, D. (2009). Robot Zot!. New York: Simon \& Schuster Books for Young Readers.

19. Simon, A. (2014). Robot Burp Head Smartypants. Somerville: Candlewick Press.

20. Simon, A. (2012). Robot Zombie Frankenstein!. Somerville: Candlewick Press.

21. Tauss, M. (2005). Superhero. New York: Scholastic Press.

22. Taylor, S. (2013). Robomop. New York: Dial Books for Young Readers.

23. Van Camp, K., \& Agnew, L. (2011). CookieBot!: a Harry and Horsie adventure. New York: Balzer + Bray.

24. Yaccarino, D. (2013). Doug Unplugged. New York: Alfred A. Knopf.

25. Brown, S. (2013). Sometimes I Forget You're A Robot. New York: Dial Books for Young Readers. 